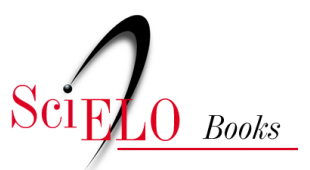

\title{
Espacialização do programa Minha Casa Minha Vida no estado e na capital do Rio de Janeiro
}

\author{
Gustavo Bezerra de Brito \\ José Silvan Borborema Araújo \\ Glaucio José Marafon
}

\section{SciELO Books / SciELO Livros / SciELO Libros}

BRITO, G. B., ARAÚJO, J. S. B., and MARAFON, G. J. Espacialização do programa Minha Casa Minha Vida no estado e na capital do Rio de Janeiro. In.: MAIA, D. S., and MARAFON, G. J., eds. O programa Minha Casa Minha Vida: habitação e produção do espaço urbano em diferentes escalas e perspectivas [online]. Rio de Janeiro: EDUERJ, 2020, pp. 113-139. ISBN: 978-65-00-03029-7. https://doi.org/10.7476/9786500030297.0005.

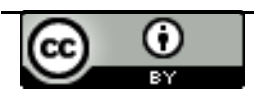

All the contents of this work, except where otherwise noted, is licensed under a Creative Commons Attribution 4.0 International license.

Todo o conteúdo deste trabalho, exceto quando houver ressalva, é publicado sob a licença Creative Commons Atribição 4.0.

Todo el contenido de esta obra, excepto donde se indique lo contrario, está bajo licencia de la licencia Creative Commons Reconocimento 4.0. 


\section{Espacialização do programa Minha Casa Minha Vida no estado e na capital do Rio de Janeiro}

Gustavo Bezerra de Brito ${ }^{1}$

José Silvan Borborema Araújo ${ }^{2}$

Glaucio José Marafon ${ }^{3}$

\section{Introdução}

Há muitas pesquisas no país que se dedicam a analisar a problemática habitacional brasileira. A falta de moradias e suas qualidades são pontos centrais para compreender a realidade contemporânea da urbanização no país. De um ponto de vista geral, é consenso que o Estado e o mercado náo foram capazes de resolver essa questáo, de maneira que a parcela da população mais atingida pelos problemas urbanos é a de baixa renda. As pessoas que compóe esta faixa de renda, segundo especialistas, são a classe social que possui mais alto déficit habitacional.

Entretanto, a partir de 2009 que um novo ponto de inflexão se faz presente. No bojo de novas regulamentaçóes no setor imobiliário, no estabelecimento de grandes metas e com o recém-criado Ministério das Cidades, ocorre o lançamento do "Programa Minha Casa Minha Vida” (PMCMV).

1 Membro do Núcleo de Estudos de Geografia Fluminense (NEGEF/UERJ). Mestrando em Geografia pela Universidade Federal do Rio de Janeiro (PPGG/UFRJ).

2 Membro do Núcleo de Estudos de Geografia Fluminense (NEGEF/UERJ). Doutor em Geografia pela Universidade do Estado do Rio de Janeiro (PPGEO/UERJ).

3 Professor Associado IGEOG/UERJ Pesquisador CNPq/CNE

4 Atualmente o Programa está na sua terceira fase (PMCMV 3). Este artigo concentra sua análise em dados do Programa até 31 de dezembro de 2018, fim do Governo de Michel Temer. 
O Programa foi criado no segundo mandato do Governo Lula e aprofundado durante o Governo Dilma e contribuiu para dar subsídios para uma nova leva de estudos no campo das políticas públicas de habitação e nos estudos de organização das cidades.

Neste sentido, podemos compreender sua relevância e representatividade a partir de dois fatores. O primeiro é a incorporação de grandes subsídios, especialmente os aportes de recursos do próprio Orçamento Geral da União (OGU) e o volume das construçóes - só na primeira fase, foram planejadas um milhão de novas moradias. $\mathrm{O}$ segundo diz respeito aos avanços em sua perspectiva social. Seu objetivo era atender especialmente às demandas das populaçóes urbanas mais pobres.

Segundo Romagnoli (2015), o contexto de seu lançamento é tempestivo na história econômica brasileira. O programa foi tomado com uma política "anticíclica" pelo Governo Federal, como meio de enfrentar a crise financeira internacional que teve início no ano de 2008. Ele foi concebido no sentido de dinamizar a construçáo civil, criar empregos e aquecer o mercado interno.

Entretanto, é notável que há fortes problemáticas identificadas no programa. Estas giram em torno da contrariedade da construção de novas habitaçóes como um modelo satisfatório de combate à falta de moradia, embora tenha havido falta de menção ao planejamento urbano, além de falta de regularização fundiária. Outras críticas são direcionadas especialmente aos padróes de inserçáo urbana dos empreendimentos - que supostamente reafirmam um modelo de urbanização excludente e precário na maior parte das cidades do país, notadamente nas regióes metropolitanas (Rolnik et al., 2015, p. 127).

No caso do Estado do Rio de Janeiro (ERJ) e da capital fluminense, esses contornos se tornam mais palpáveis. É a partir de dados do Ministério do Desenvolvimento Regional (MDR) coletados até o fim de 2018 que podemos ilustrar a seguinte hipótese: embora inovador na concessão de subsídios para habitação de setores de renda baixa, além de ampliador de crédito para imóveis de camadas intermediárias da população, o programa não tomou o território como o aspecto central da política de moradia direcionada a sanar os problemas adequados nessa questão.

Sendo assim, neste trabalho nos preocupamos em verificar, por meio da análise dos dados quantitativos e cartográficos do ERJ e da capital Rio de Janeiro, um possível aumento da segregação socioespacial no estado em 
função da renda, além da concentração de unidades habitacionais nas faixas intermediárias com maior poder aquisitivo - notadamente as faixas 2 e 3 .

$\mathrm{O}$ artigo estrutura-se em três partes interligadas. Começamos discutindo brevemente aspectos gerais sobre o funcionamento e execução do PMCMV, tendo em vista que ao longo dos dez anos desde o seu lançamento, o Programa é alvo de inúmeras pesquisas e levantamentos sobre habitação do país. Na primeira parte, suas principais características são então explicitadas. No segundo momento, o Estado do Rio de Janeiro é o enfoque: a partir da análise do material cartográfico, expandimos os dados para apresentar as particularidades do ERJ. Por fim, tecemos consideraçôes sobre a associação dessa política pública e os padrôes identificados pela análise realizada.

\section{Aspectos gerais do Programa Minha Casa Minha Vida}

É notável que o Programa, uma política pública de habitação do Governo Federal brasileiro, possui um significado forte no discorrer das políticas de habitaçáo nos últimos anos. Seja por seus impactos econômicos, territoriais ou sociais, é considerado ponto central na história da moradia no país. Em termos práticos, foi responsável por reposicionar a questáo da habitaçáo na agenda governamental. Segundo Hervé $(2017$, p. 2), "este é o programa mais significativo no campo da habitação no país nos últimos trinta anos".

Após um hiato de mais de duas décadas de descaso com a questão habitacional a nível federal, com exceção de açôes singulares que não chegaram a provocar mudanças estruturais (Bonduki, 2008), o Programa Minha Casa Minha Vida foi regulamentado pela Lei n. ${ }^{\circ} 11.977$, de 7 de julho de 2009, que o estrutura a partir do Programa Nacional de Habitação Urbana (PNHU) e Programa Nacional de Habitaçáo Rural (PNHR).

No que tange aos objetivos e investimentos, a expectativa era alta. Em sua primeira fase, foram programadas a construção de 1 milhão de moradias num prazo relativamente curto, dois anos. Foram utilizados 34 bilhóes no total de investimentos, divididos em $\mathrm{R} \$ 25,5$ bilhōes no Orçamento Geral da União e R \$ 7,5 bilhôes do Fundo de Garantia por Tempo de Serviço (FGTS). Além disso, ficou previsto ainda um investimento de R\$ 1 bilhão para a infraestrutura urbana, distribuído pelo Banco Nacional de Desenvolvimento Econômico e Social (BNDES). 
Para as famílias com renda de até três salários mínimos, a meta era construir 400 mil unidades do PMCMV com um pagamento mensal, considerado simbólico, de R \$50,00. Para famílias com renda de 3 a 6 salários mínimos também se tinha como objetivo construir 400 mil unidades pelo PNHU. Para as famílias com renda de 6 a 10 salários mínimos, o objetivo era construir 200 mil unidades com o financiamento do FGTS. O produtor rural, por sua vez, solicitaria o financiamento de acordo com a sua renda (Cardoso e Aragão, 2013 apud Andrade, 2012).

Ainda nesta trilha de investigação, é interessante a análise do Gráfico 1, onde é possível identificar a maior incidência do déficit habitacional no país. Sendo este o somatório entre os componentes habitação precárias, coabitação familiar, ônus excessivo em aluguel e adensamento excessivo (FGV, 2018). A compreensão do problema é maior quando atrelada a problemáticas urbanas como violência, desigualdade, transporte deficitário, falta de infraestrutura de luz, saneamento etc.

Gráfico 1 - Distribuição relativa do Déficit Habitacional por Faixa de Renda Familiar - 2017

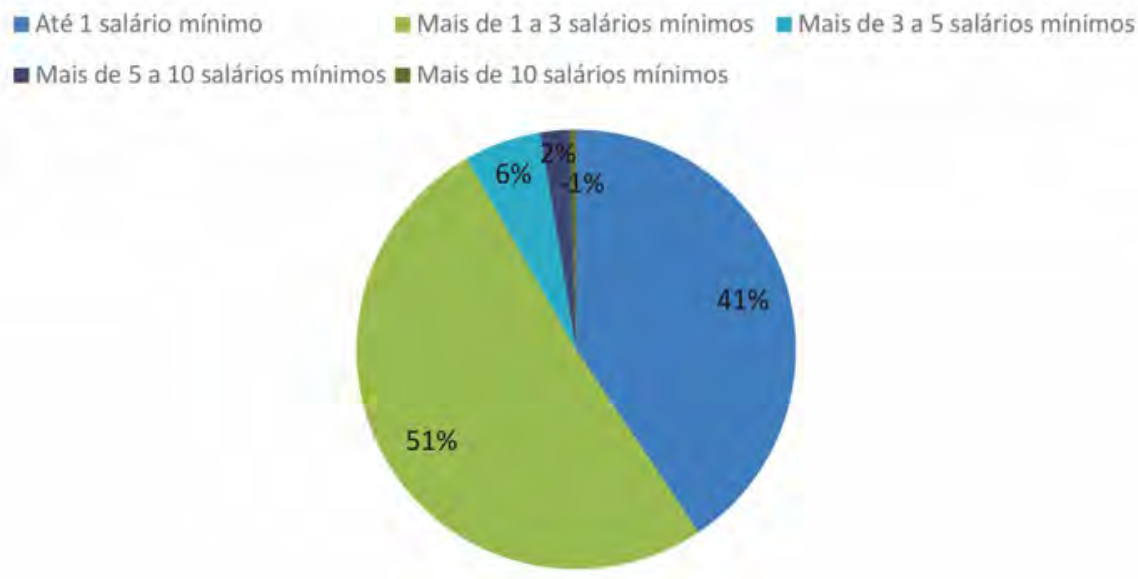

Fonte: Fundação Getúlio Vargas, 2018.

Logo, em termos da distribuição do déficit total por faixas de renda, nota-se a forte concentração nos estratos até três salários mínimos. Somadas, as faixas de renda até 1 salário mínimo e de 1 a 3 salários mínimos corresponderam por $91,7 \%$ do déficit total, o equivalente a 7,1 milhóes de unidades. 
Desta maneira, o Programa adequou os seus objetivos ao concentrar a maior parte da construção de unidades para a população que mais contribui nesta problemática.

Nesse contexto, onde o déficit habitacional brasileiro se concentra majoritariamente na população de baixa renda, as principais orientaçôes restavam em reduzir em $14 \%$ o déficit de moradias no Brasil, especialmente em municípios com mais de 100 mil habitantes, além de dinamizar o setor de construção civil, responsável por 5,7\% do PIB nacional (Romagnoli, 2012).

Já nas fases 2 e 3, iniciadas no governo de Dilma Rousseff, o prazo de duração previsto foi maior, de três anos, e com a meta de construção de 2 milhóes de unidades habitacionais. Para estas etapas, 60\% das unidades seriam destinadas às famílias com menor faixa de renda, até $\mathrm{R} \$ 1.600,00 ; 30 \%$ para a segunda faixa, entre $\mathrm{R} \$ 1.600,00$ e $\mathrm{R} \$ 3.100,00$; e $10 \%$ para a última faixa, $R \$ 3.100,00$ a $R \$ 5.000,00$ (Quadro 1). O Programa passa a ser operacionalizado, portanto, com três faixas de renda e náo quantidade de salários mínimos, como ocorreu em sua primeira edição (Ramos e Noia, 2014).

Quadro 1 - Metas de contratação do MCMV II

\begin{tabular}{l|c|c}
\hline Renda & Unidades & $\%$ \\
\hline Até R\$ 1.600 & 1.200 .000 & $60 \%$ \\
\hline 1.600 a 3.100 & 600.000 & $30 \%$ \\
\hline 3.1000 a 5.000 & 200.000 & $10 \%$ \\
\hline Total & 2.000 .000 & $100 \%$ \\
\hline
\end{tabular}

Fonte: Brasil, 20195. Elaboração própria.

Foi na fase 2 que seus recursos foram ampliados, com previsão de aporte da ordem de " 125 bilhôes de reais, sendo 72,6 bilhóes de reais orientados aos subsídios e 53,1 bilhôes de reais para os financiamentos" (Andrade, 2012, p. 53). Houve ainda mudanças operacionais: a agregação do Banco do Brasil ao Programa, visando propiciar mais agilidade nos processos de contratação, acompanhamento das obras, financiamento e repasse de recursos.

5 Dados da Secretaria de Governo do Brasil. Disponível em http://www.secretariadegoverno.gov.br/iniciativas/internacional/fsm/eixos/inclusao-social/minha-casa-minha-vida.Acesso em 2019. 
Além dessas mudanças, especificações técnicas dos apartamentos foram alteradas para incluir a obrigatoriedade da utilização de cerâmica no piso de todos os cômodos e a destinação de 3\% das unidades de cada empreendimento para pessoas com deficiências físicas (estas moradias são adaptadas com portas e banheiros maiores).

Apesar do montante de investimentos alocados e contornos de assistencialismo e redistribuição de renda, o programa é alvo de críticas diversas por parte de diferentes setores da sociedade. Boa parte da argumentaçáo gira em torno do grande atraso no cronograma de obras e da qualidade dos imóveis entregues.

Há exemplos notáveis de unidades que são contratadas e não foram entregues. Além disso, muitas são tidas como concluídas embora apresentem condiçôes como paredes desalinhadas, buracos na alvenaria, pintura malfeita, louças fora do padrão, goteiras e infiltraçóes (Andrade, 2012, p. 56)

Ademais, há críticas que afirmam que, apesar do Programa apresentar metas que tocam a questão urbana do país, são superficiais. Arantes e Fix (2009) argumentam que o PMCMV não possui nenhum dispositivo que estimule a reutilização de imóveis antigos não ocupados, que delimitariam a funçáo social da propriedade. Em sua maioria, as unidades habitacionais contratadas são construídas do zero.

Segundo os autores, esta última alternativa não é necessariamente a melhor maneira de enfrentar os problemas de habitação. As alternativas que dão conta de repetir e adaptar políticas públicas que transcorrem em outros países, notadamente a criação de fundos públicos para aquisição, desapropriação e aluguel subsidiado de unidades habitacionais, com a intenção de diminuir o déficit, além de enfrentar a especulação imobiliária e o crescimento da malha urbana seriam mais adequadas.

Ademais, não há diretrizes que incentivem as construtoras a promoverem a construção de imóveis em áreas centrais, já densamente urbanizadas e com infraestrutura, em lotes menores ou para requalificação de edifícios, práticas mais coerentes na proposta do PMCMV.

Borges (2013), por sua vez, indica que $97 \%$ do subsídio público no programa é destinado à oferta e produçáo direta por construtoras privadas, deixando de lado a regulamentação de planos diretores. Esta seria uma dificuldade por parte dos municípios para a efetiva aplicaçáo dos instrumentos previstos no Estatuto da Cidade, tornando a iniciativa privada protagonista. 
Rolnik et al (2015, p. 148) também destacam que existem outras formas de prover moradia, além da produção de novas unidades. Motivadas pela desarticulação entre as diretrizes da política e pelo Plano Nacional de Habitacão (PNH), ocorre a inibição de outras soluçôes habitacionais previstas, como a urbanização de assentamentos precários e construção em parceria com entidades organizadoras.

Este quadro contribuiria com o fenômeno da segregação socioespacial nas cidades - novamente, uma tendência de utilização de terrenos mais baratos, consequentemente, afastados da malha urbana. ${ }^{6} \mathrm{O}$ PMCMV seria omisso na questáo urbana, mesmo prevendo as condiçóes mencionadas acima.

Emínia Maricato, em entrevista concedida em 2010, afirma que um Programa de tamanha relevância para o setor deveria apresentar formas de tocar no estatuto da propriedade fundiária, buscando regular ganhos especulativos e garantir a função social da propriedade. O PMCMV, em sua visão, caracteriza um retrocesso diante da evolução conquistada e já devidamente consolidada na legislação urbanística do país.

No Estado do Rio de Janeiro, sobremaneira, este fenômeno tem contornos mais significativos. Com boa parte da sua população vivendo na Região Metropolitana (RMRJ), o estado apresenta uma forte tendência à concentração metropolitana. Náo nos surpreende, ao analisarmos o Quadro 2, que a RMRJ contribui em cerca de 66\% no déficit habitacional do Estado. No interior fluminense, esta taxa é de $34 \%$.

Quadro 2 - Déficit Habitacional no Estado do Rio de Janeiro - 2015

\begin{tabular}{|c|c|c|}
\hline \multirow[t]{2}{*}{ Especificação } & \multicolumn{2}{|c|}{ Déficit Habitacional no Estado do Rio de Janeiro - 2015} \\
\hline & Total & $\%$ no Estado \\
\hline RMRJ & 304.083 & $66 \%$ \\
\hline Interior Fluminense $^{7}$ & 155.977 & $34 \%$ \\
\hline Total ERJ & 460.785 & $100 \%$ \\
\hline
\end{tabular}

Fonte: Dados básicos do Instituto Brasileiro de Geografia e Estatística (IBGE), Pesquisa Nacional por Amostra de Domicílios (PNAD). Elaboração própria, 2019.

${ }^{6}$ Edificadas nas periferias, contribuindo para a formaçáo de cidades fragmentadas e custosas, haja visto que será necessário a instalação de novos equipamentos públicos nessas áreas.

7 Municípios fora da RMRJ. 
Neste sentido, o estado possui chances significativas de apresentar os problemas anteriormente citados. Cabe a nós, então, avaliarmos a situação das unidades habitacionais no estado, a fim de verificar os resultados de uma política pública que, supostamente, tenta sanar a questão da habitação, mas que por inabilidade dos instrumentos de organização das cidades, pode contribuir com a segregaçáo e a desigualdade social.

Ressaltamos também que, para a efetiva compreensão dos mapas que serão apresentados, é importante conhecer algumas das características do ERJ, notadamente sua divisão política administrativa e os elementos norteadores da organização especial fluminense. Neste sentido, sugerimos a leitura de Marafon et al (2011) a fim de contribuir com análises dos aspectos sociopolíticos antigos e atuais que configuram as regióes do estado.

\section{Espacialização do Programa Minha Casa Minha Vida no Estado do Rio de Janeiro}

Levando em consideração a ampla dimensão do Programa Minha Casa Minha Vida, que envolve variados aspectos de caráter socioeconômico, político e cultural, devemos atentar para a questão da sua espacialização e efetivação na entrega das unidades habitacionais no território do estado do Rio de Janeiro.

Localizado na região Sudeste do país (mapa 1), com uma população estimada para 2019 de aproximadamente 17.264.943 habitantes (IBGE, 2019), o déficit habitacional é expressivo, principalmente na Região Metropolitana, embora não isente outras regióes administrativas do estado. 
Mapa 1 - Regióes de Governo e Municípios - Estado do Rio de Janeiro

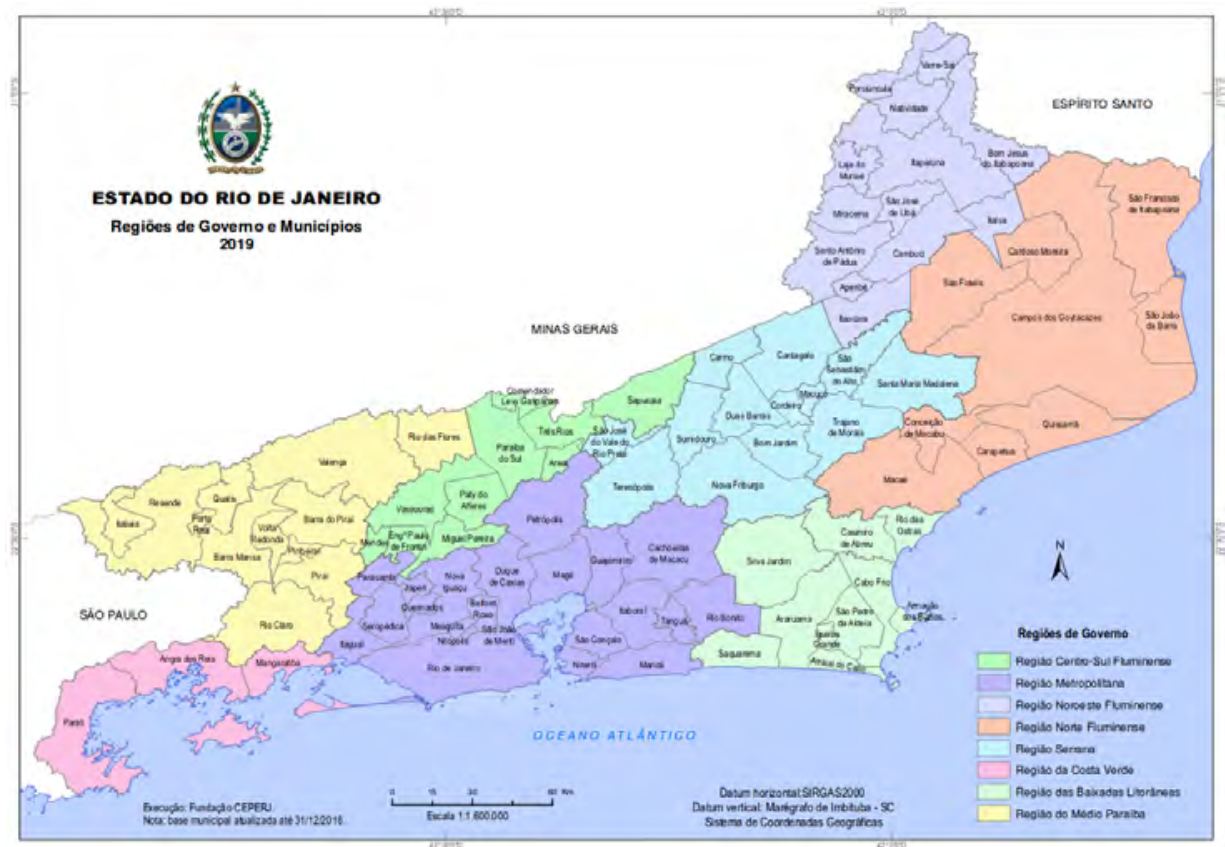

Fonte: CEPERJ, 2019.

Nesse cenário, o programa se espacializou em todas as regióes do estado, distribuído nas três faixas de renda, ${ }^{8}$ embora, dentre as unidades contratadas, a entrega tenha ocorrido com maior destaque na faixa 3 , destinada à classe social com maior poder aquisitivo.

No entanto, a faixa 1, destinada às famílias de baixa renda, de até três salários mínimos, foi a que apresentou os menores números de unidades (mapa 2) se comparado às outras faixas de renda.

${ }_{8}$ Salientamos que, além das faixas 1, 2 e 3, o Programa também atendeu a uma faixa intermediária para quem recebe até 1,5 salário mínimo. Não contemplamos esta faixa na nossa análise, uma vez que não resultou em quantidades expressivas de unidades contratadas, concluídas e entregues e que não interfere na análise do Programa no estado do Rio de Janeiro. 
Mapa 2 - Unidades contratadas para a faixa 1 do PMCMV

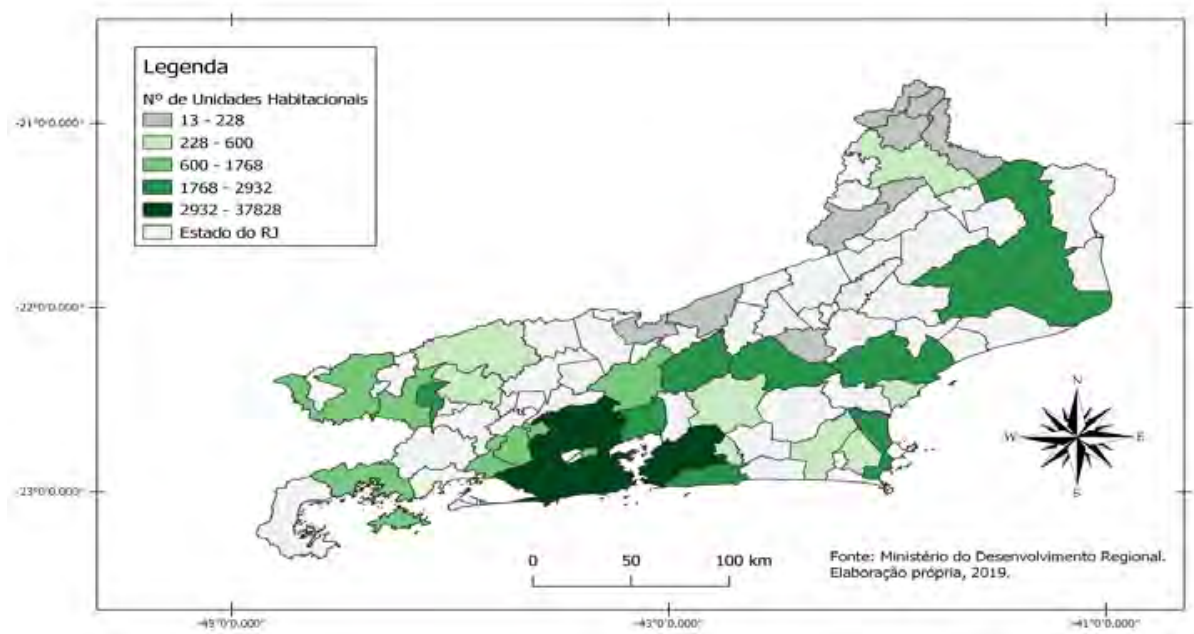

Fonte: Ministério do Desenvolvimento Regional. Elaboração própria, 2019.

Diante do exposto, podemos perceber que esta etapa do Programa esteve espacializada em todas as regiốes do estado, embora não tenha contemplado muitos municípios interioranos. Notamos que teve maior concentração na Região Metropolitana, com o número de unidades expressivo, variando entre 2.932 a 37.828 unidades contratadas, abrangendo a capital Rio de Janeiro e os municípios de Duque de Caxias, Belford Roxo, Nova Iguaçu, Queimados, Niterói, São Gonçalo e Itaboraí. Além disso, alguns municípios que polarizam outras regiôes administrativas do estado também receberam unidades contratadas da faixa 1. Municípios como Campos dos Goytacazes, Teresópolis, Nova Friburgo, Macaé, Cabo Frio, Maricá, Magé e Volta Redonda apresentaram números de unidades contratadas variando entre 1.768 a 2.932. As demais regióes do estado não foram contempladas com um número expressivo de unidades contratadas para esta faixa. Sendo assim, o maior número dessa faixa ficou concentrado nos municípios supramencionados, deixando de contemplar grande parte do território estadual.

Importante destacar que a tendência de espacialização das unidades para a faixa 1 segue a tendência também nas outras etapas do programa, embora apresente déficit na etapa de conclusão e na entrega das unidades (mapas 3 e 4): 
Mapa 3 - Unidades concluídas para a faixa 1 do PMCMV

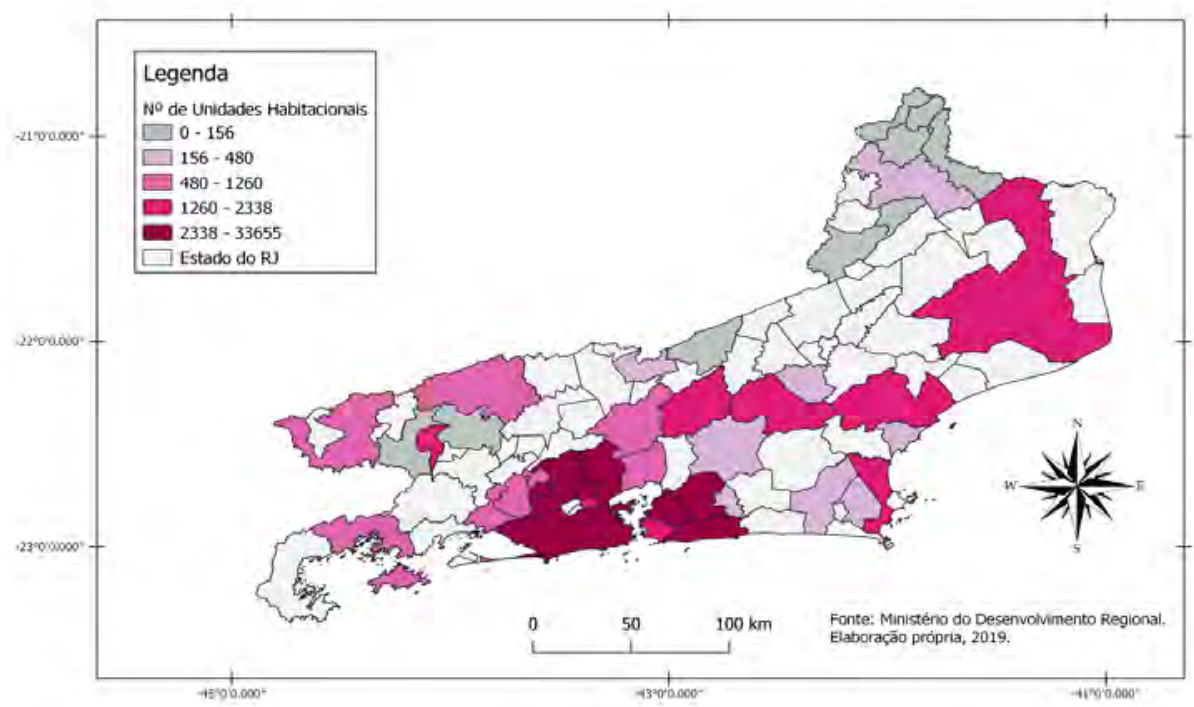

Fonte: Ministério do Desenvolvimento Regional. Elaboração própria, 2019.

As unidades concluídas, logicamente, concentram-se nas áreas onde houve mais unidades contratadas. No entanto, percebemos que, nessa etapa do programa, municípios como Nova Friburgo, na Região Serrana, conseguiram entregar uma quantidade de unidades bem acima da média, considerando que o município possuía entre 1.260 a 2.338 unidades concluídas e, desse total, configura-se na classe entre 2.128 a 32.702 unidades entregues (mapa 4). Ou seja, Nova Friburgo pode ter entregue todas as unidades contratadas. Isso se deve ao fato do município ter sido atingido por uma tragédia climática em 2011, em que grande parte da população perdeu os seus imóveis nas enchentes. 
Mapa 4 - Unidades Entregues para a faixa 1 do PMCMV

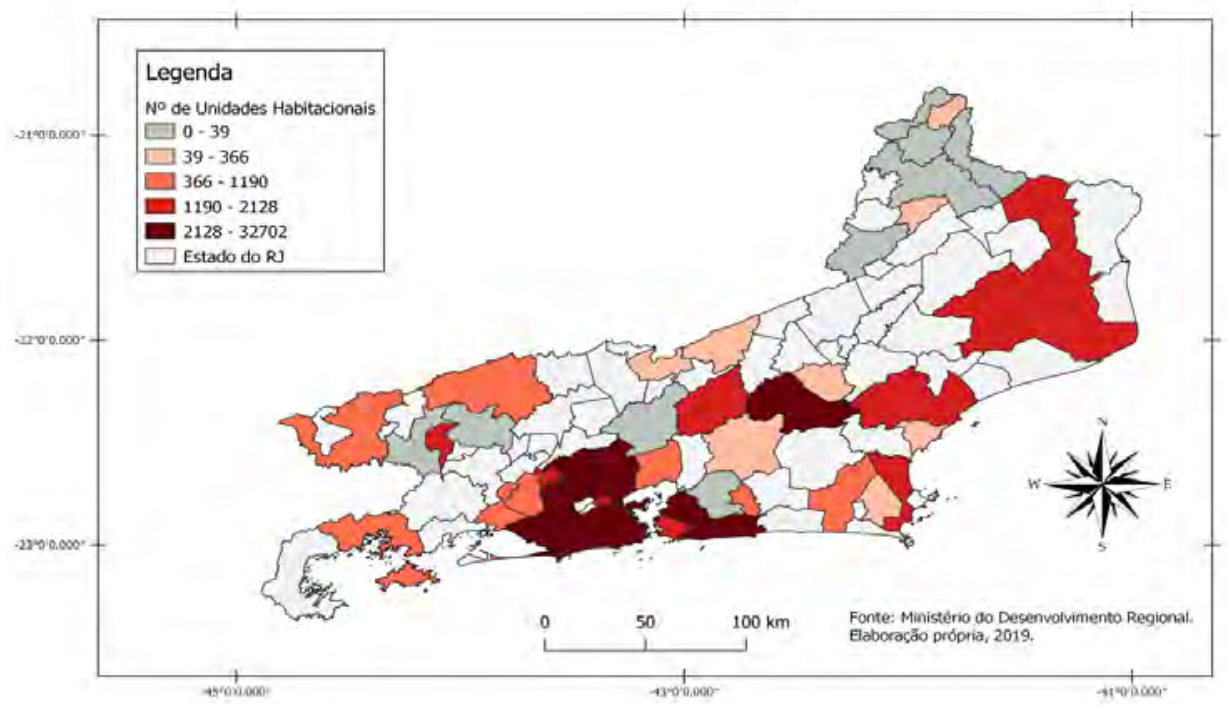

Fonte: Ministério do Desenvolvimento Regional. Elaboração própria, 2019.

Sendo assim, analisando a espacialização das unidades entregues para a faixa 1 do Programa, confirmamos a espacialização seletiva do processo. De fato, a região metropolitana, por concentrar maior contingente populacional, possui um déficit maior na questão de habitação, o que justifica a maior concentração de unidades na área, contudo, municípios que apareciam com unidades contratadas foram perdendo a sua participação na medida em que o programa avançava, não conseguindo entregar as unidades.

Percebemos que as unidades para a faixa 1 do Programa foram concentradas espacialmente, com menor número de unidades tanto contratadas, quanto concluídas e entregues, apesar deste grupo ser o mais vulnerável no que diz respeito ao déficit habitacional e enfoque do programa.

Levando em consideração as unidades destinadas à faixa 2 , que atendeu famílias com renda de 3 a 6 salários mínimos, apresenta maior espacialização, aparecendo com mais expressividade em todas as regióes do estado e em todas as modalidades (contratadas, concluídas e entregues) (mapa 5). 
Mapa 5 - Unidades contratadas para a faixa 2 do PMCMV

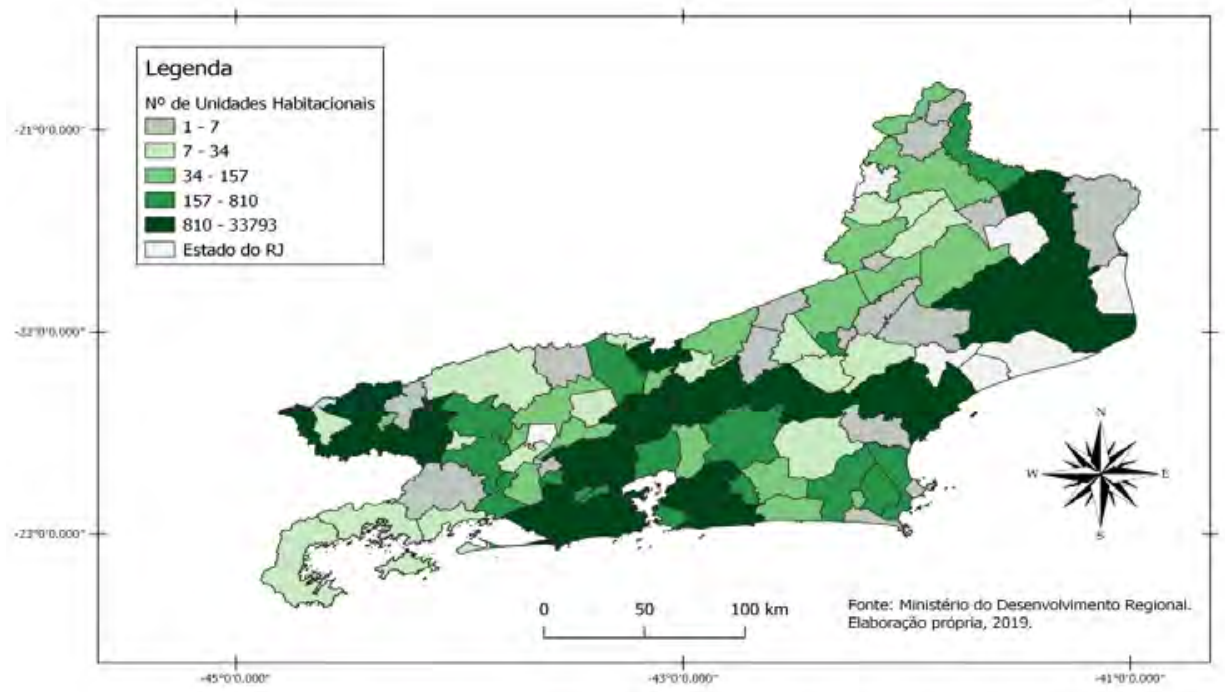

Fonte: Ministério do Desenvolvimento Regional. Elaboração própria, 2019.

Além dos municípios já citados na faixa 1 , aparecem com mais unidades os municípios de Petrópolis, Rio das Ostras, Três Rios, Barra Mansa e Resende. Estes municípios participam presenciando os maiores números de unidades contratadas, variando de 810 a 33.793 unidades.

$\mathrm{Na}$ faixa 2, apesar das outras etapas terem apresentado uma leve diminuição de unidades, não representam grandes variaçóes se comparado com as diferenças verificadas na faixa 1 (mapa 6). 
Mapa 6 - Unidades concluídas para a faixa 2 do PMCMV

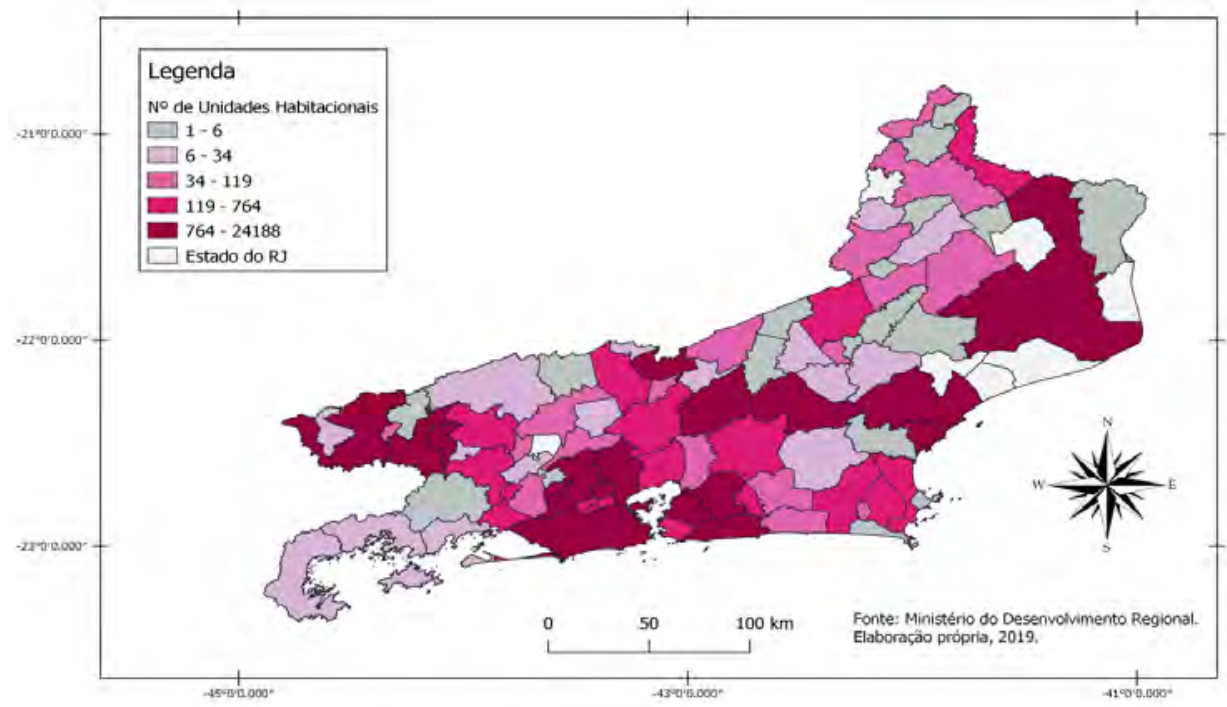

Fonte: Ministério do Desenvolvimento Regional. Elaboração própria, 2019.

De modo geral, não houve interrupção entre as etapas de contratação e conclusão das unidades habitacionais para a faixa 2. É possível perceber que os mesmos municípios que apresentaram unidades contratadas tiveram as unidades concluídas, não gerando perdas significativas para esta faixa.

A mesma tendência foi seguida para a etapa final do programa, com a entrega das unidades (mapa 7), onde todos os municípios que possuíam unidades contratadas conseguiram entregá-las, sem interrupção das etapas. 
Mapa 7 - Unidades entregues para a faixa 2 do PMCMV

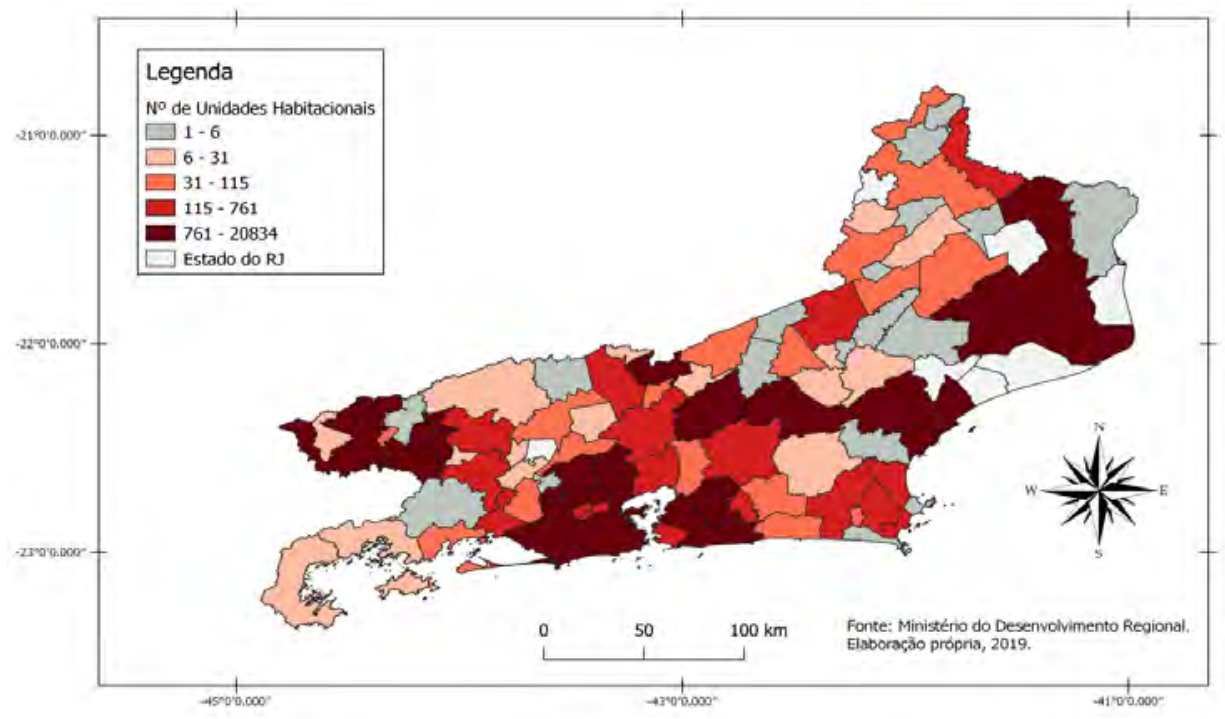

Fonte: Ministério do Desenvolvimento Regional. Elaboração própria, 2019.

Sendo assim, podemos observar que, para esta faixa de renda, o Programa conseguiu cumprir significativamente com as etapas, entregando mais de $50 \%$ das unidades contratadas em cada área do estado. Vale ainda ressaltar que, de maneira geral, a faixa 2 apresenta maior número de unidades em relação à faixa 1 .

No que diz respeito à faixa 3 do programa, destinada às famílias com renda entre 6 e 10 salários mínimos, verificamos uma menor espacialização em relação às faixas 1 e 2, embora ainda maior que a primeira faixa (mapa 8). 
Mapa 8 - Unidades contratadas para a faixa 3 do PMCMV

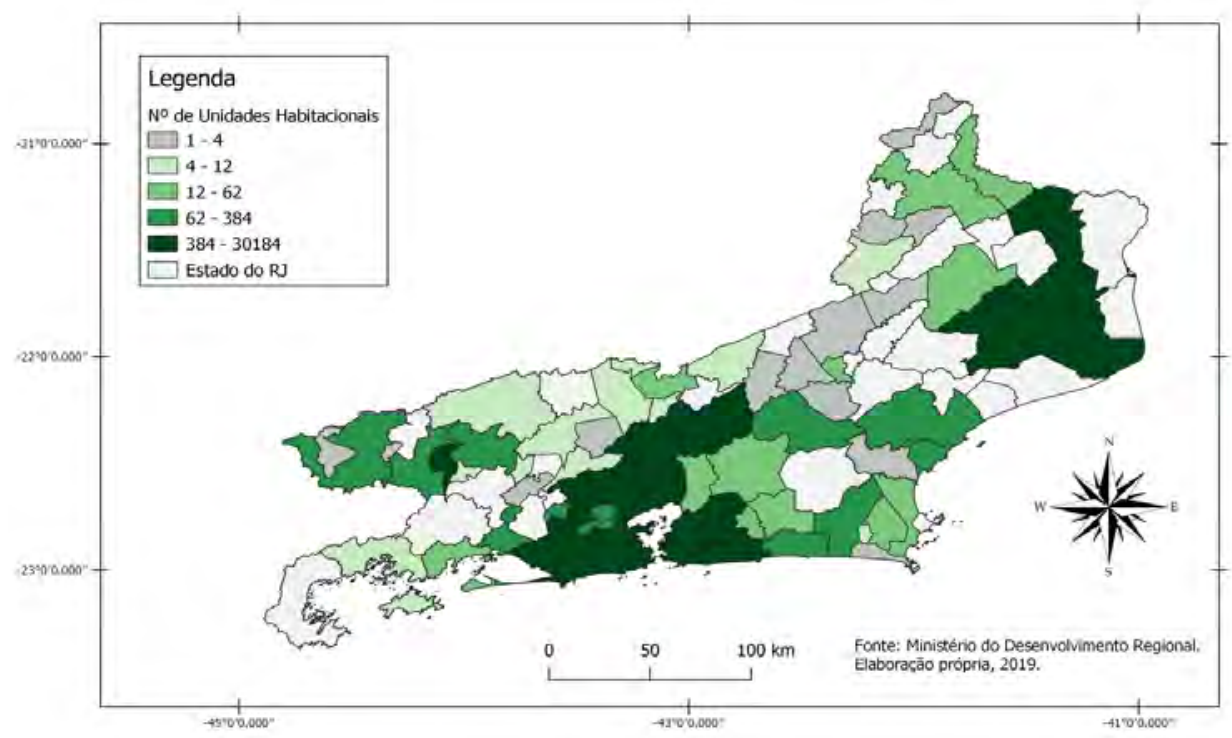

Fonte: Ministério do Desenvolvimento Regional. Elaboração própria, 2019.

Como tendência de espacialização para todas as faixas, a área da RMRJ concentra as maiores unidades, em todas as etapas, ficando menos denso no interior do estado, embora esteja presente em todas as regiōes.

Essa espacialização mais uniforme pelo território estadual vai se repetir nas outras etapas do programa, a exemplo das unidades concluídas (mapa 9), não apresentando perdas significativas dessas unidades em relação às unidades contratadas. 
Mapa 9 - Unidades concluídas para a faixa 3 do PMCMV

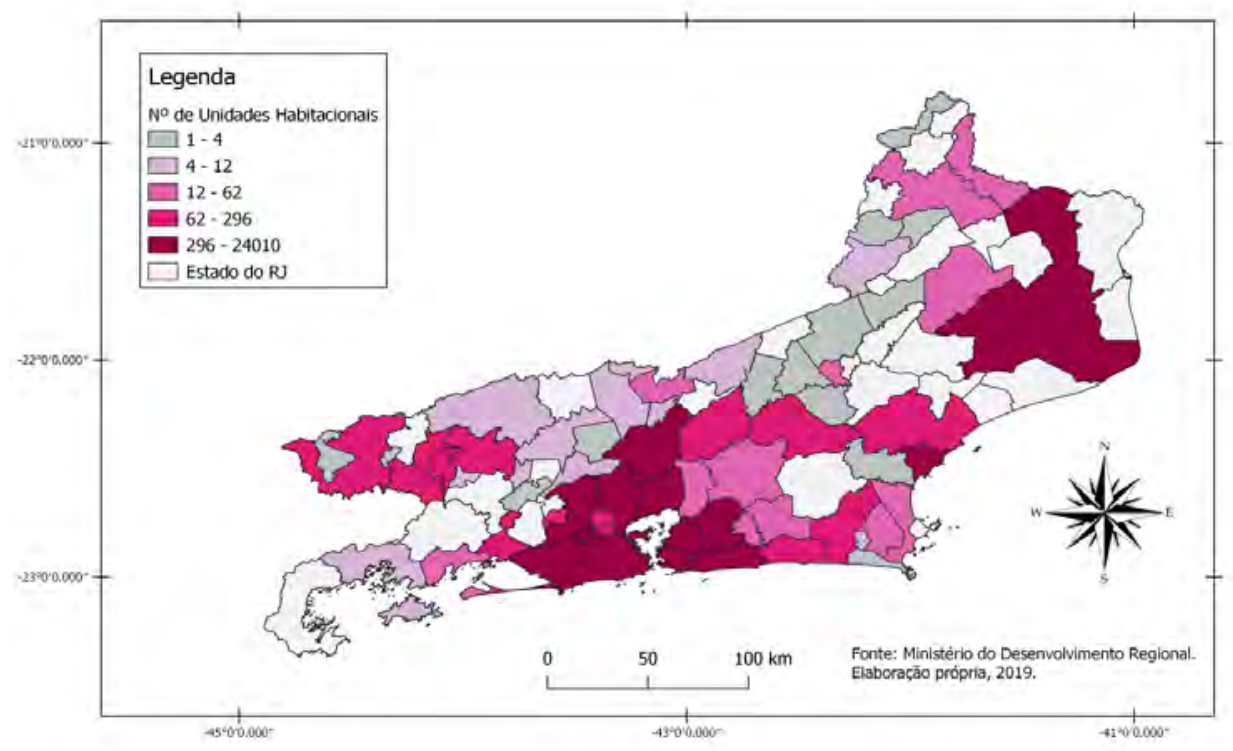

Fonte: Ministério do Desenvolvimento Regional. Elaboração própria, 2019.

Como dito, nesta etapa a espacialização do programa pelos municípios do estado permaneceu a mesma, não havendo perdas significativas de unidades concluídas. Embora nesta faixa o programa tenha conseguido manter o maior número unidades, de maneira geral, referente às contratadas e concluídas, na etapa de unidades entregues houve pequena, mas significativa perda, como percebido no mapa 10. 
Mapa 10 - Unidades entregues para a faixa 3 do PMCMV

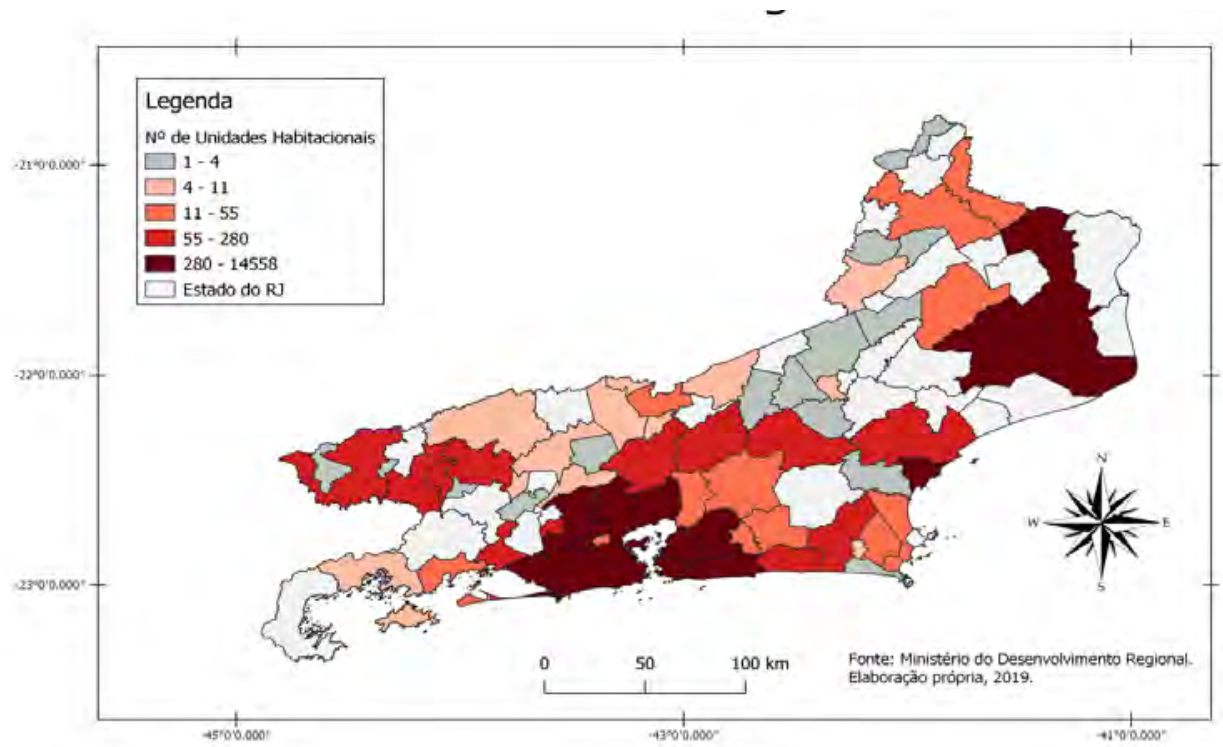

Fonte: Ministério do Desenvolvimento Regional. Elaboração própria, 2019.

Diante disso, podemos reafirmar que esta faixa apresenta melhor continuidade das unidades que foram contratadas, concluídas e entregues. Estando concentradas na maioria dos municípios da RMRJ, nos municípios de Campos dos Goytacazes e Rio das Ostras, com unidades entregues variando entre 280 a 14.558. Resende, Barra Mansa, Volta Redonda, Barra do Piraí, Itaguaí, Queimados, Petrópolis, Teresópolis, Nova Friburgo, Macaé, Maricá e Araruama participam com unidades entregues variando entre 55 a 280.

Nesse contexto, percebemos o caráter seletivo e até excludente do programa, no qual as faixas 2 e 3 , foram mais privilegiadas que a faixa 1 . Isso envolve a escolha de melhores locais dentro das cidades, que não apresentem sérios riscos, infraestrutura, formato das unidades (que não são necessariamente apartamentos, mas também casas), entre outros aspectos.

Para a faixa 1, que o subsídio do governo era maior e contemplava a maioria da população com déficit habitacional, os interesses do setor imobiliário parecem ter prevalecido, não havendo um estudo prévio sobre as condiçóes de risco, além de desrespeitar a origem das pessoas que seriam contempladas com o programa, como foi o caso do Terra Nova, em Nova Friburgo, onde famílias de variadas origens, ao terem seus imóveis perdidos 
pela tragédia, foram realocadas para uma área mais distante de seu local de origem e sem a garantia de uma qualidade de vida, porque lhes faltava uma série de serviços básicos.

Todavia, esta realidade não se apresenta apenas no interior do estado, mas também na capital, como será possível perceber na próxima seção.

\section{Espacializaçáo do Programa Minha Casa Minha Vida no município do Rio de Janeiro}

A grande demanda por habitação encontrada no estado do Rio de Janeiro também foi sentida pelo Programa Minha Casa Minha Vida na capital, principalmente para o segmento da faixa 1 do programa.

No entanto, seguindo a mesma lógica do que ocorreu no estado, esta faixa de renda náo se especializou por todas as áreas do território municipal, concentrando-se mais na regiáo oeste (mapa 11).

Mapa 11 - Unidades Contratadas para a faixa 1 do PMCMV na capital do Rio de Janeiro

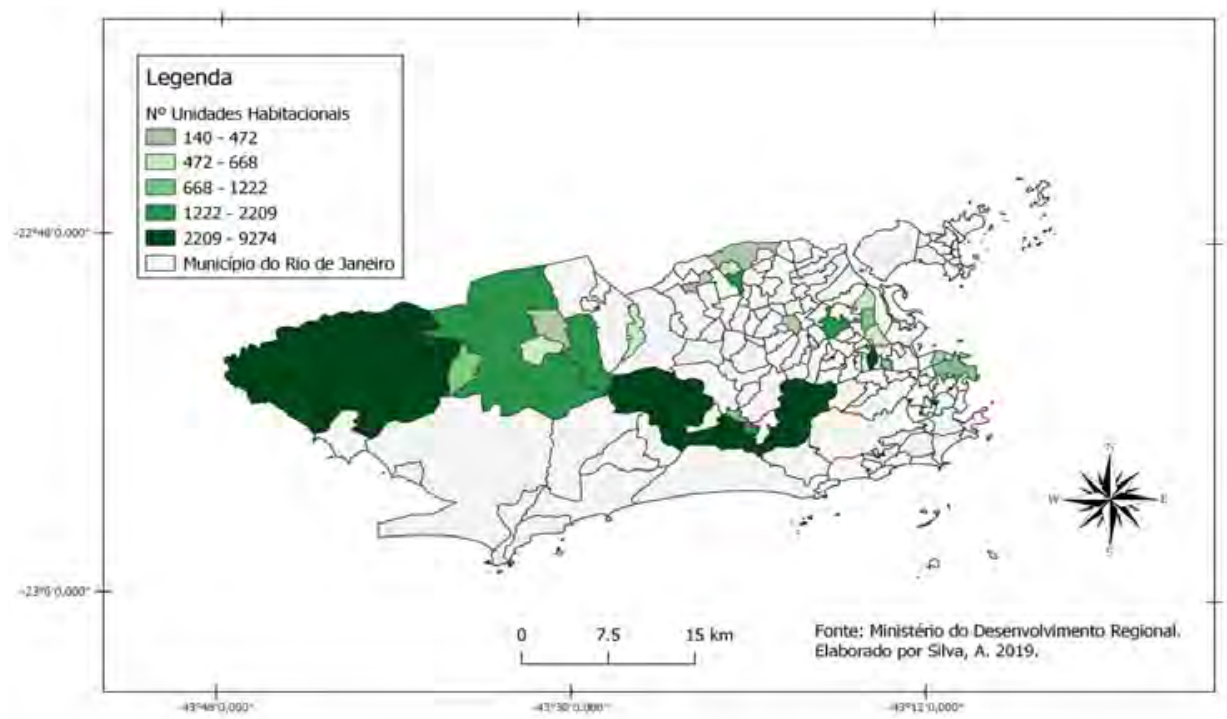

Fonte: Ministério do Desenvolvimento. Elaboração: Silva, 2019. 
Nesse sentido, bairros como Santa Cruz, no extremo oeste, além de Paciência e Jacarepaguá presenciaram uma quantidade maior de unidades contratadas para esta faixa, variando entre 2.209 a 9.274 unidades.

A mesma lógica de espacialização seguiu com a faixa 2 (mapa 12), em que a maioria dos bairros da zona oeste foram contemplados com unidades contratadas, embora para esta faixa apareçam bairros que não estavam na faixa anterior.

Mapa 12 - Unidades contratadas para a faixa 2 do PMCMV na capital do Rio de Janeiro

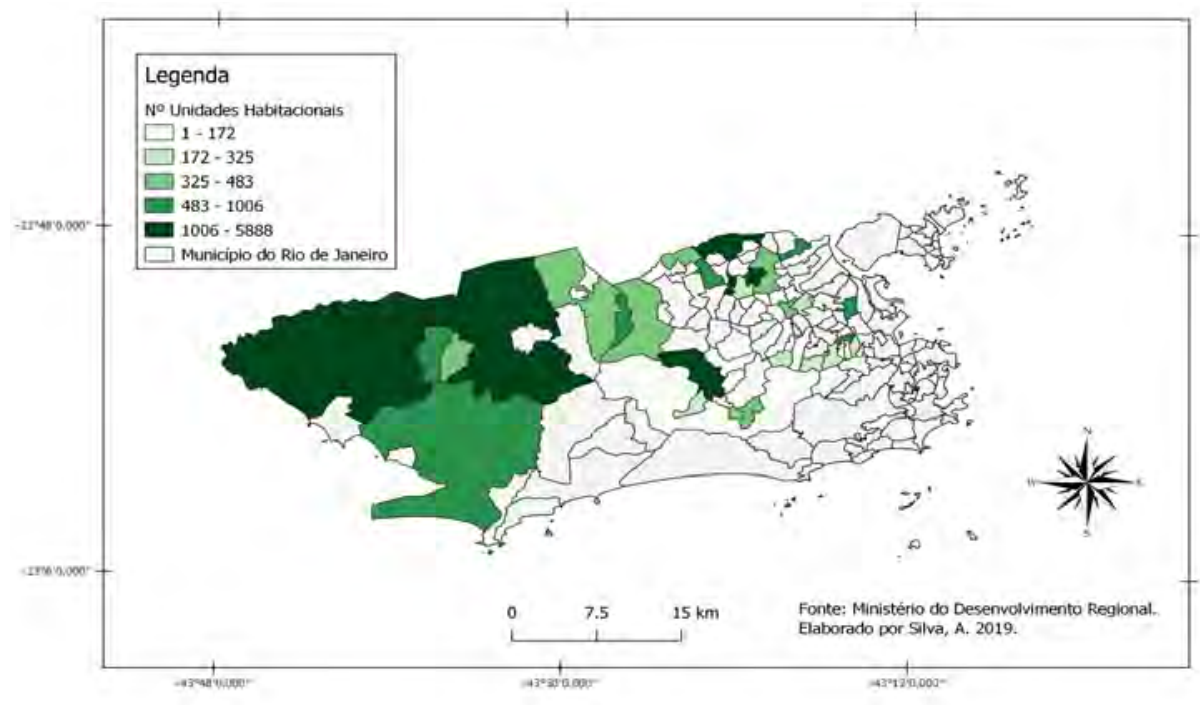

Fonte: Ministério do Desenvolvimento. Elaboração: Silva, 2019.

No entanto, percebemos que, das unidades contratadas para a faixa 3, o programa se espacializou com mais intensidade também pela zona norte da capital fluminense (mapa 13): 
Mapa 13 - Unidades contratadas para a faixa 3 do PMCMV na capital do Rio de Janeiro

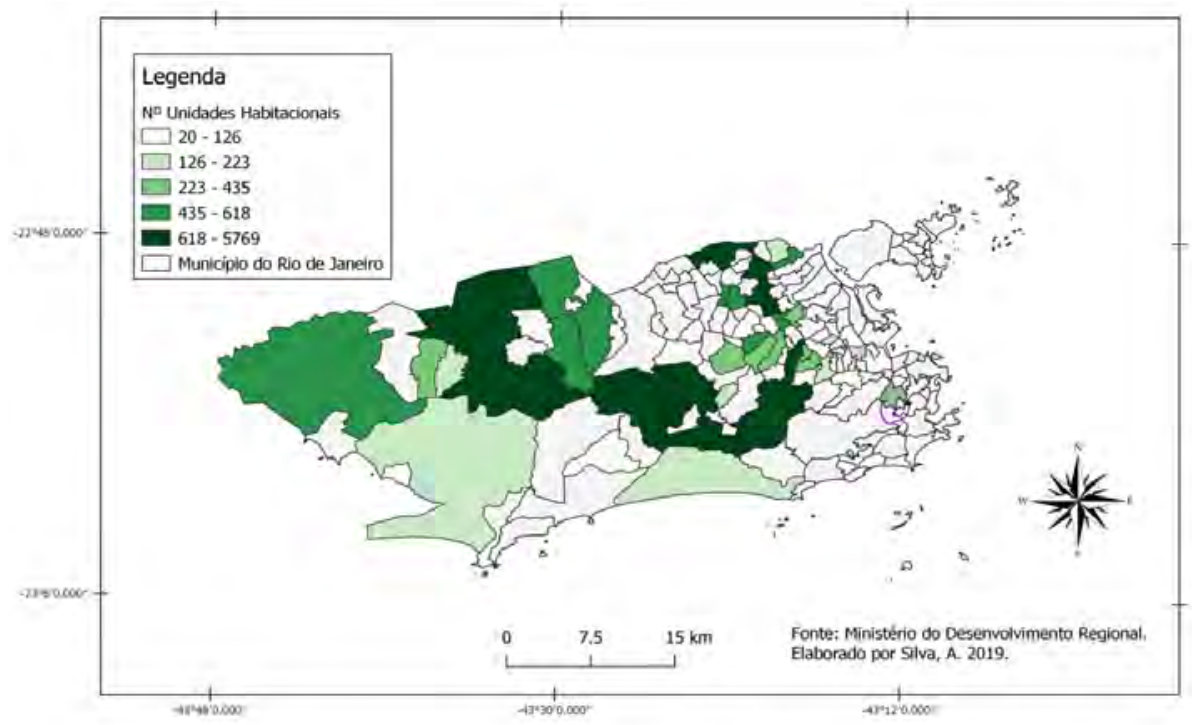

Fonte: Ministério do Desenvolvimento. Elaboração: Silva, 2019.

Nesse cenário, quando observamos as unidades que foram concluídas, notamos que houve um decréscimo do quantitativo em todas as faixas, embora mantendo certa estabilidade nos bairros em que estão espacializados. Ou seja, os bairros que apresentaram mais unidades contratadas conseguiram manter a quantidade de mais unidades concluídas (mapas 14, 15 e 16): 
Mapa 14 - Unidades concluídas para a faixa 1 do PMCMV na capital do Rio de Janeiro

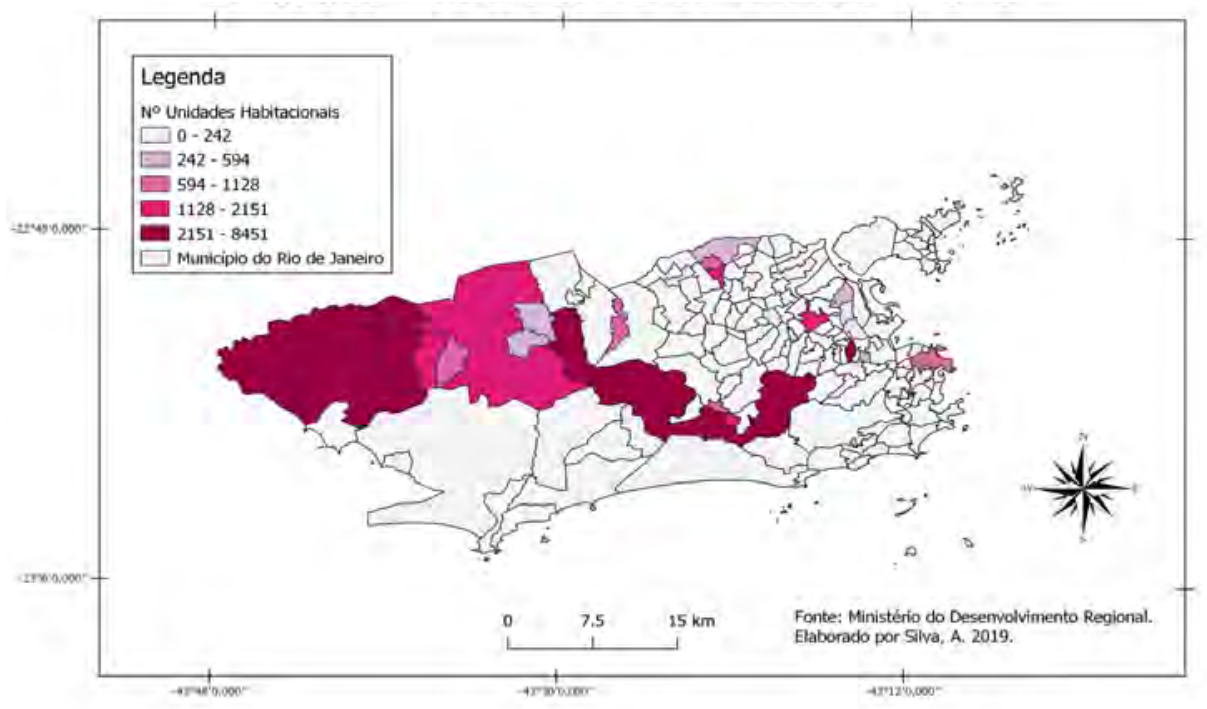

Fonte: Ministério do Desenvolvimento. Elaboração: Silva, 2019.

Mapa 15 - Unidades concluídas para a faixa 2 do PMCMV na capital do Rio de Janeiro

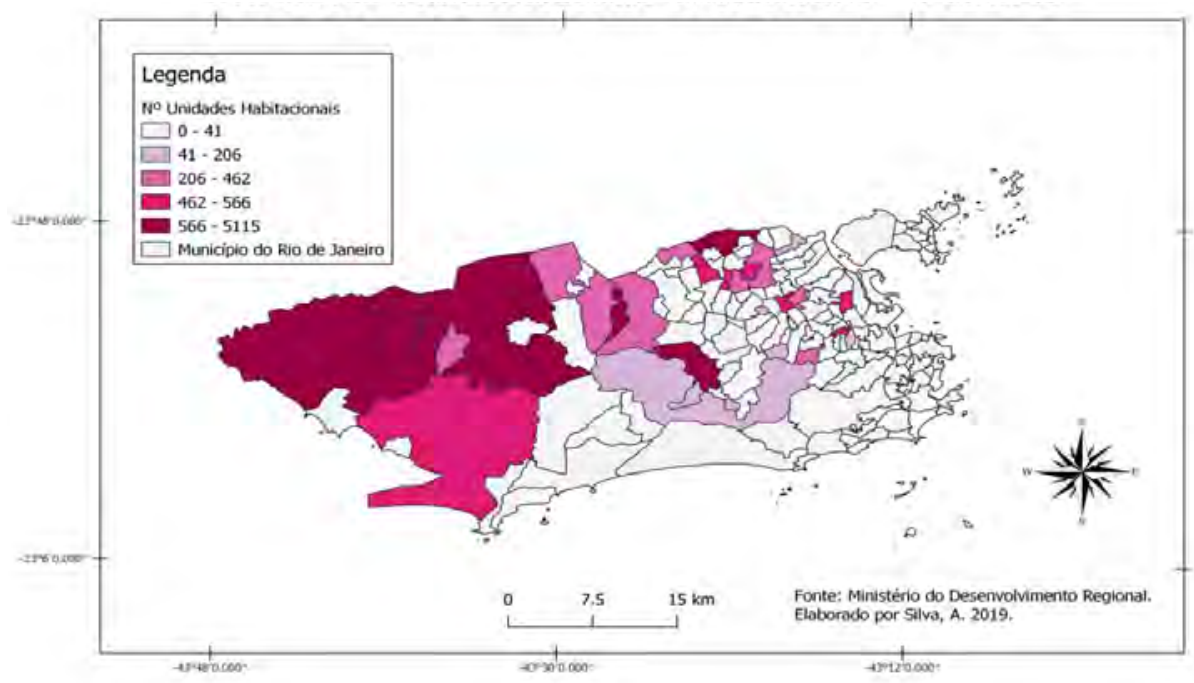

Fonte: Ministério do Desenvolvimento. Elaboração: Silva, 2019. 
Mapa 16 - Unidades concluídas para a faixa 3 do PMCMV na capital do Rio de Janeiro

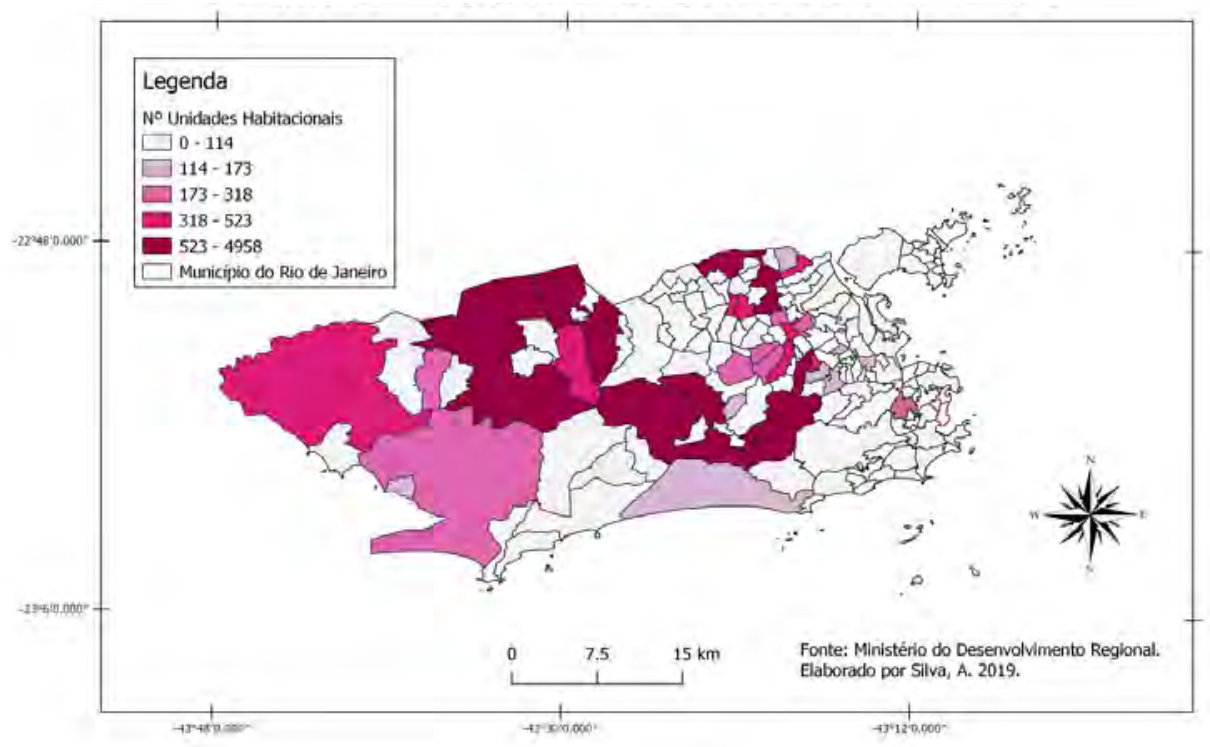

Fonte: Ministério do Desenvolvimento. Elaboração: Silva, 2019.

Diante desse contexto, reforçamos a lógica do programa para todas as faixas. Para as duas primeiras (faixa 1 e 2), as unidades tiveram maior concentração na zona oeste, enquanto que para a faixa 3 o programa se espacializou também pela zona norte.

Sendo assim, a mesma lógica seguiu também para as unidades entregues, tendo uma perda leve para a faixa 1 e um pouco mais significativa para as faixas 2 e 3 (mapas 17, 18 e 19) 
Mapa 17 - Unidades entregues para a faixa 1 do PMCMV na capital do Rio de Janeiro

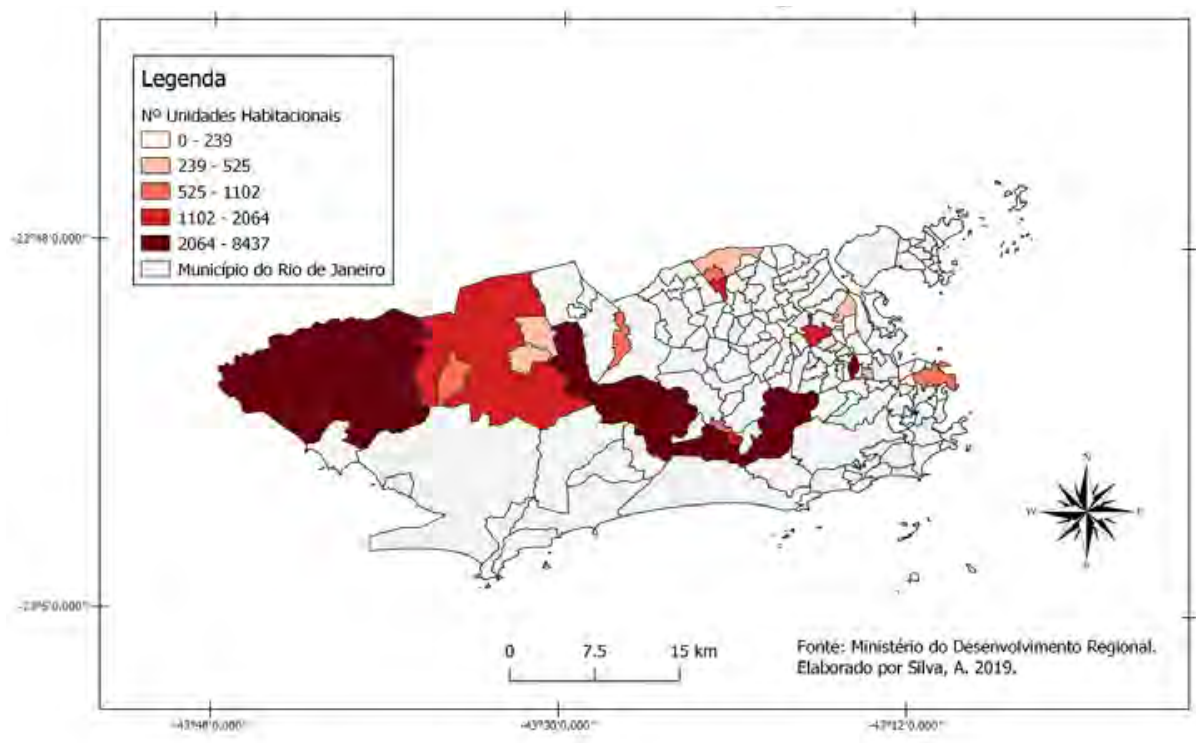

Fonte: Ministério do Desenvolvimento. Elaboração: Silva, 2019.

Mapa 18 - Unidades entregues para a faixa 2 do PMCMV na capital do Rio de Janeiro

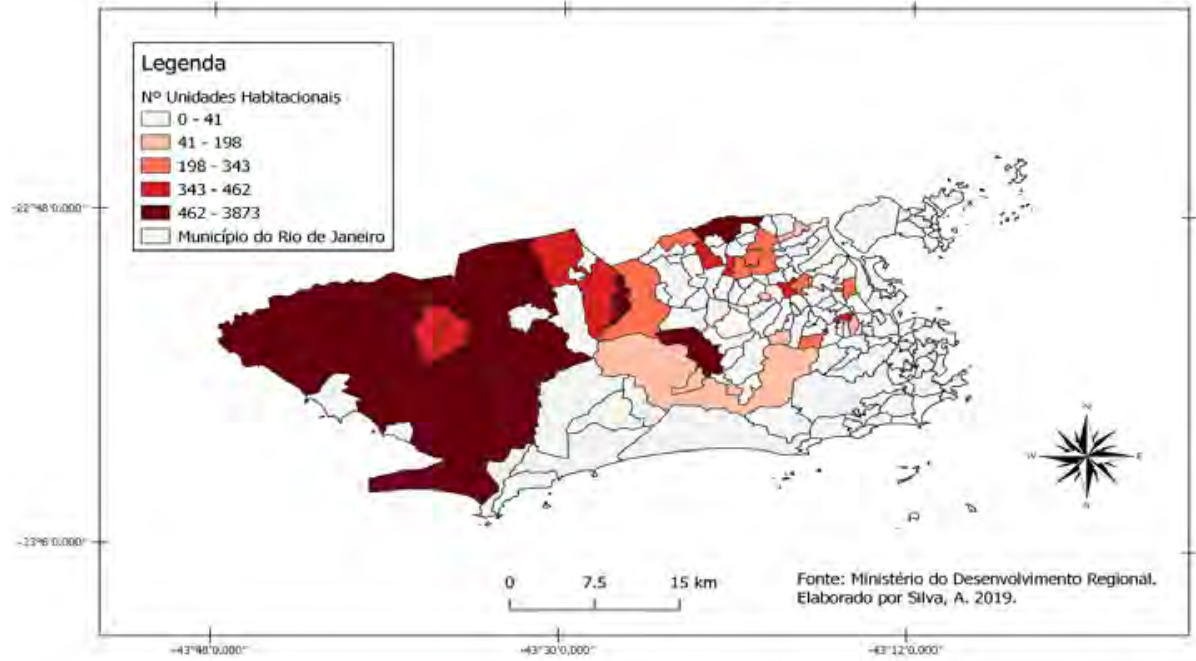

Fonte: Ministério do Desenvolvimento. Elaboração: Silva, 2019. 
Mapa 19 - Unidades entregues para a faixa 3 do PMCMV na capital do Rio de Janeiro

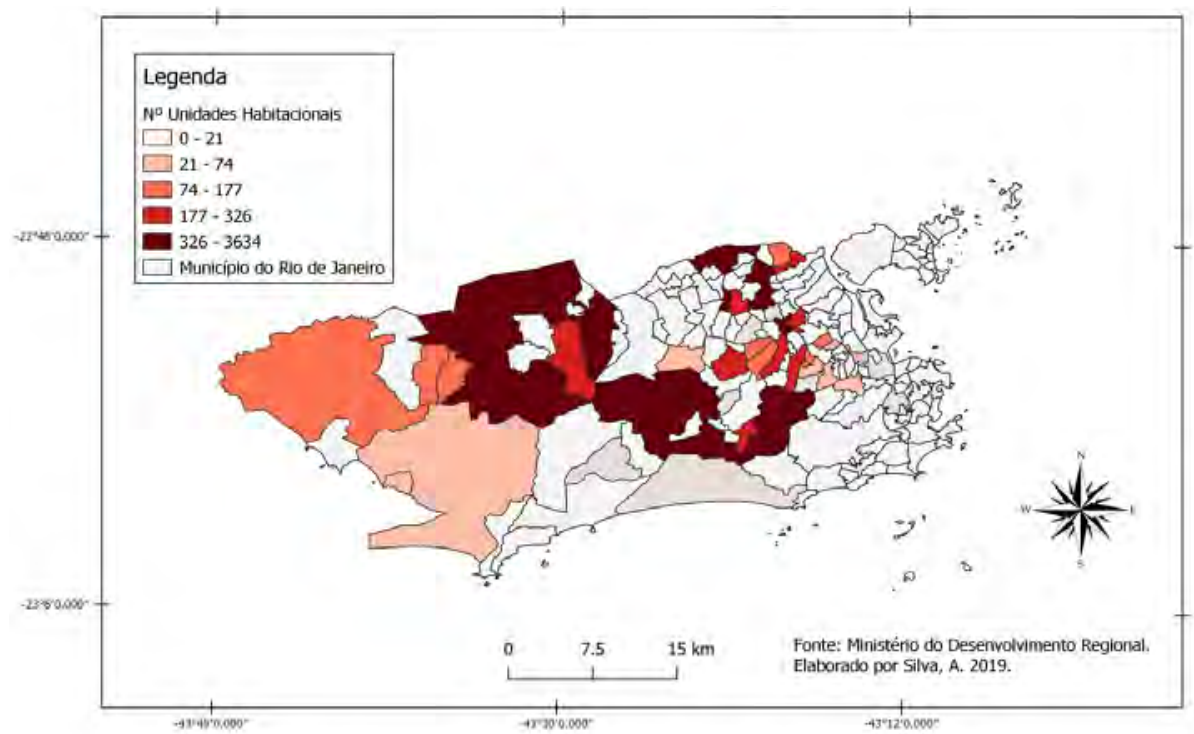

Fonte: Ministério do Desenvolvimento. Elaboração: Silva, 2019.

No geral, é possível identificar, com base na leitura dos mapas, uma concentração bastante significativa do PMCMV nas zonas oeste e norte da capital fluminense, inexistindo para todas as faixas na zona sul e muito pouco na área central.

De todo modo, o programa que deveria privilegiar a faixa social que mais necessita e sofre com o problema de habitação no estado e na capital do Rio de Janeiro deixou algumas lacunas. Isso fica mais visível quando analisamos os mapas para a faixa 1 nas três modalidades, sobretudo em relaçáo à localização das unidades, infraestrutura de toda a área do entorno dos condomínios, além da completa entrega das unidades. É preciso políticas públicas de qualidade e que levem em conta a diversidade de áreas e interesses presentes no nosso território para que, assim, sejam efetivadas.

\section{Consideraçóes finais}

Pensando as políticas públicas para habitação no país nas últimas décadas, pudemos perceber ao longo do capítulo que o Programa Minha Casa 
Minha Vida desempenhou papel de importante relevância para esta pasta do governo federal, uma vez que reposicionou a questão da habitação no país, além de ter impulsionado a economia, retardando o enfrentamento da crise que já vinha sendo enfrentada por outros países.

Considerando que as estimativas de construção de moradias nas três etapas analisadas do Programa - iniciado no governo Lula, em 2011, continuado até o governo Temer, em 2018 - chegaria a 3 milhóes de unidades, a maioria dessas unidades deveria privilegiar o grupo da populaçáo que recebia até 1 salário mínimo, haja vista o grande número de pessoas no país e, consequentemente, no estado do Rio de Janeiro, que sofrem com essa questão.

No entanto, as ações para minimização do problema do déficit habitacional no país pelo PMCMV ainda deixaram algumas lacunas que não foram preenchidas, principalmente no que diz respeito à faixa 1 , classe de rendimento que mais sofre com a questão de falta de moradia.

No estado do Rio de Janeiro, bem como na capital, esta faixa foi a que mais apresentou problemas nas três etapas de execuçáo do programa (contratação, conclusão e entrega), além de problemas relacionados à localização dos loteamentos, que de modo geral, ficavam muito distantes dos centros das cidades e das áreas onde as pessoas desenvolviam as suas vidas. Também apresentou problemas referentes à falta de serviços no entorno dos empreendimentos, o que força essa população a buscá-los em outras áreas da cidade. Enfim, a faixa social que mais necessitava das açôes do programa não teve suas aspiraçóes alcançadas em um sentido mais amplo para o estabelecimento de uma vida mais confortável.

Por outro lado, as faixas 2 e 3 do programa viram-se mais contempladas em vários aspectos, variando de localizaçáo à modalidade de moradia (casa ou apartamento). Pode-se dizer que as unidades contratadas, concluídas e entregues para essas faixas foram muito consideráveis se comparadas à faixa 1, enfoque do programa.

Para a capital fluminense, percebemos que o programa se concentrou na zona oeste do município, apresentando também unidades na zona norte, principalmente quando destinada para as faixas 2 e 3 .

Nesse sentido, embora o PMCMV tenha tido alguns pontos falhos na sua execução, não podemos deixar de salientar seu aspecto positivo ao garantir a habitação para milhóes de brasileiros e, em especial, para a população do 
estado e da capital do Rio de Janeiro. Um contingente considerável do estado conseguiu garantir a casa própria a partir deste programa.

\section{Referências}

ANDRADE, Gabriel Vieira Marx. Políticas Habitacionais Brasileiras: Uma Avaliaçáo do Programa Minha Casa, Minha Vida em suas duas ediçôes (Dissertação). Rio de Janeiro, 2012. ARANTES, Pedro Fiori e FIX, Mariana. "Como o governo Lula pretende resolver o problema da habitação". Caros Amigos, pp. 1-25, 2009. Disponível em: https://xa.yimg.com/kq/ groups/14917735/451095191/name/Pacote_Pedro_Mariana_Final_COMPLETO.pdf. Acesso em 2019.

BONDUKI, N. "Política habitacional e inclusão social no Brasil: revisão história e evolução no Governo Lula. Revista Eletrônica de Arquitetura e Urbanismo, São Paulo, n. 1, pp. 70-104, 2008.

BORGES, Raphael Melo. Análise de desempenho térmico e acústico de unidades habitacionais construidas no conjunto habitacional Benjamin José Cardoso em Viçosa-MG. (Dissertação). Viçosa: Universidade Federal de Viçosa, 2013.

Fundação CEPERJ - Centro Estadual de Estatísticas, Pesquisas e Formação de Servidores Públicos do Rio de Janeiro. Cartografia fluminense, 2019. Disponível em: <http://www. ceperj.rj.gov.br/>. Acesso em 2019.

Fundação Getúlio Vargas. Análise das necessidades habitacionais e suas tendências para os próximos 10 anos. Rio de Janeiro, 2018.

HERVÉ, Thery. "Novas Paisagens Urbanas do Programa Minha Casa, Minha Vida”. Mercator - Revista de Geografia da UFC., Fortaleza, v. 16, n. 1, 2017.

IBGE - Instituto Brasileiro de Geografia e Estatística. População do estado do Rio de Janeiro. Disponível em: https://cidades.ibge.gov.br/brasil/rj/panorama Acesso em: 24 set. 2019.

MARAFON, G. J. (orgs.). Geografia do Estado do Rio de Janeiro: Da compreensão do passado aos desafios do presente. Rio de Janeiro: Gramma, 2011. $161 \mathrm{p}$.

MARICATO, Erminia. "O 'Minha Casa' é um avanço, mas segregação urbana fica intocada". Carta Maior, maio 2009. Disponivel em http://cartamaior.com.br. Acesso em: mar. 2010.

Portal Brasileiro de Dados Abertos. Indicadores sobre o Programa Minha Casa, Minha Vida. 2016.

RAMOS, J. da S. e NÓIA, A. C. "Análise da execução do Programa Minha Casa Minha Vida nos municípios de Ilhéus e Itabuna, Bahia". Semana do Economista, 4., Encontro de Egressos, 4., Ilhéus, 2014. pp. 1-20.

ROMAGNOLI, Alexandre J. "O programa 'minha casa, minha vida': continuidades, inovaçôes e retrocessos”. In: Temas de Administração Pública - TEMAP., São Paulo, v. 4, n. 7, pp. 1-29, 2012.

ROLNIK, Raquel et al. "O Programa Minha Casa Minha Vida nas regiôes metropolitanas de São Paulo e Campinas: aspectos socioespaciais e segregação”. In: Cad. Metrop., São Paulo, v. 17, n. 33, pp. 127-54, 2015. 